\title{
Pembuatan prototipe Aluminium cylinder head engine dengan metode rapid prototyping dan investment casting
}

\author{
Masy’ari $^{\star \star}$, Ari Dwi Prasetiyo²${ }^{2}$ Edi Karyadi ${ }^{3}$ \\ 1,2,3Jurusan Teknik Mesin, Politeknik Negeri Pontianak \\ Jl. Akhmad Yani, Pontianak, Indonesia \\ *Corresponding author:masyari_ari@yahoo.com
}

\begin{abstract}
The manufacturing industry is one of the sectors that consistently continues to provide the largest national economic growth contribution to reach the target economic growth of 5.3\% in 2020. In the 4.0 industry era, the manufacturing industry sector in Indonesia starts to adopt the newest digital technology like artificial intelligence, machine learning, and the internet of things, and additive manufacturing. This research aimed to develop a manufactured product in form of Aluminium cylinder head engine prototype with digital rapid prototyping and Aluminium investment casting. To reach the research goal, the research started from theoretical study and data collection. Next, the cylinder head engine is modelled in CAD (computer-aided design software and printed in $3 D$ printer with polyvinyl butyral and polylactic acid. This $3 D$ printed cylinder head is going to use as moulding pattern. Hereafter, the cylinder head engine is assembled with gating system and coated with a mix of cement plaster, silica sand, and kaolin soil. After the mould is dry, the mould will be burned until the $3 D$ printed pattern is vaporized. The final step is pouring the molten Aluminium at $800^{\circ} \mathrm{C}$ temperature into the mould. The results showed that the casting process with a cylindrical gating system was perfectly formed, especially for the fins part. However, for the smaller fins, there were still defects in form of lumps. The mix of silica sand, gypsum cement and kaolin soil can create a strong mould. The difference in pattern material does not have a significant effect on the investment casting mould-making process.
\end{abstract}

Keywords: Rapid prototyping, cylinder head engine, investment casting.

\begin{abstract}
Abstrak
Industri manufaktur adalah salah satu sektor yang masih terus konsisten memberikan kontribusi terbesar pada perekonomian nasional dalam mencapai target pertumbuhan ekonomi nasional sebesar 5,3\% di tahun 2020. Era Revolusi Industri 4.0, sektor industri manufaktur Indonesia mulai gencar mengadopsi teknologi digital terbaru, seperti artificial intelligence, machine learning, internet of things, dan addictive manufacturing. Penelitian ini bertujuan mengembangkan suatu produk manufaktur dalam bentuk prototipe Aluminium cylinder head engine dengan teknologi digital yaitu metode rapid protityping dan sistem produksi investment casting. Penelitian dimulai dengan melakukan studi literatur dan pengumpulan data. Penggambaran cylinder head engine menggunakan CAD (computer-aided design). Pembuatan pola cetakan menggunakan mesin 3D Printer dengan material resin plastik polyvinyl butyral dan polylactid acid. Gating system digambar pada software CAD dan dicetak pada 3D printer. Pola cetakan dan gating system disatukan dan dilapisi dengan lapisan campuran semen plaster, pasir silika, dan tanah kaolin. Setelah lapisan kering, cetakan dipanaskan hingga pola cetakan menguap dan tidak bersisa. Proses pengecoran dilakukan pada pre-heating cetakan $300{ }^{\circ} \mathrm{C}$ dan temperatur penuangan $800^{\circ} \mathrm{C}$. Hasil penelitian menunjukkan bahwa hasil coran dengan sistem saluran berbentuk silindris sudah terbentuk sempurna terutama untuk bagian-bagian sirip, namun untuk ukuran sirip yang lebih tipis (ukuran sirip sebenarnya) masih terdapat cacat pada beberapa permukaan sirip berbentuk gumpalan-gumpalan. Komposisi material cetakan pasir
\end{abstract}


silika, semen gypsum dan tanah kaolin dapat menghasilkan cetakan yang cukup kuat terlihat dari pre-heating tidak terdapat retak. Pengaruh material pola cetakan tidak memberikan pengaruh yang signifikan terhadap proses pembuatan cetakan investment casting.

Kata Kunci: cylinder head engine, investment casting, rapid prototyping.

\section{Pendahuluan}

Industri manufaktur adalah salah satu sektor yang masih terus konsisten memberikan kontribusi terbesar pada perekonomian nasional dalam mencapai target pertumbuhan ekonomi nasional sebesar 5,3\% di tahun 2020 [1]. Di era Revolusi Industri 4.0 ini sektor industri manufaktur Indonesia mulai gencar mengadopsi teknologi digital terbaru, seperti artificial intelligence, machine learning, dan internet of things (IoT) [2]. Sehingga banyak sektor industri manufaktur mulai melakukan inovasi proses produksi memanfaatkan teknologi digital, seperti industri pengecoran logam. Dengan adanya inovasi sistem produksi ini diharapkan dapat mengefesiensikan proses produksi melalui sentuhan teknologi baru yang ada di era industri 4.0.

Politeknik Negeri Pontianak (POLNEP) tentunya harus ikut berperan serta dalam pengembangan ilmu pengetahuan dan teknologi (IPTEK) era Revolusi Industri 4.0, khususnya pengembangan teknologi digital terbaru, sebagaimana yang tertuang dalam fokus riset unggulan institusi yaitu teknologi informasi dan komunikasi (teknologi digital) serta material maju untuk mendukung industri [3].

Terkait dengan pengembangan IPTEK tersebut, penulis telah melakukan penelitian dalam bidang pengecoran logam, yaitu pemanfaatan potensi sumber daya mineral Kalimantan Barat untuk pembuatan prototipe aluminium cylinder head engine menggunakan pengecoran lost foam [4][5]. Hasil penelitian pembentukan pola stryofoam menggunakan konsep kawat pemanas dengan mesin CNC konvensional dapat dimanfaatkan sebagai pembentuk pola stryofoam, namun masih terkendala untuk pembentukan pola yang lebih komplit, hasil coran masih terdapat cacat penyusutan (shrinkage), bentuk geometri dan ketelitian masih rendah dan permukaan coran masih terlihat kasar. Untuk itu, masih dibutuhkan penelitian lanjutan pengecoran logam yang terkendali dengan metode sistem pengecoran yang lain.

Sedangkan terkait dengan bidang teknologi digital penulis juga telah melakukan penelitian yaitu penerapan teknik digital prototyping dalam perancangan dan pembuatan model turbin cross flow [6]. Kemudian melakukan penelitian tentang penerapan teknik digital prototyping dalam perancangan dan pembuatan model produk berbasis generative design [7].

Industri pengecoram logam sabagai industri manufaktur yang banyak memproduksi komponen mesin, dalam proses produksinya membutuhkan waktu yang lama, seperti persiapan pembuatan pola dan cetakan. Semakin rumit bentuk dan ukuran benda yang akan dibuat menjadi faktor penentu durasi pembuatan pola cor, sehingga pembuatan dan kualitas pola coran menjadi kunci penting dalam proses pengecoran. Oleh karena itu, penelitian ini sangat menentukan keberlangsungan untuk pengembangan pembuatan pola cylinder head engine menggunakan metode rapid prototyping dan pengecoran investment casting.

\section{Tinjauan Pustaka}

\section{Perkembangan teknologi rapid prototyping di masa depan}

Berdasarkan hasil studi literatur perkembangan teknologi rapid prototyping dalam Jurnal Metris [8], bahwa teknologi Rapid Prototyping termasuk teknologi yang sangat flexible dan mudah diintegrasikan dengan berbagai teknologi. Kemudahan dalam membuat produk dalam waktu yang relatif singkat membuat orang tertarik untuk mempelajari dan memanfaatkan teknologi 
ini. Beberapa tahun di belakang, teknologi rapid prototyping dengan mesin 3Dnya menjadi teknologi yang masih mahal dan sulit diterima akal. Akan tetapi jika melihat kondisi saat ini, teknologi ini mulai bisa dinikmati dengan biaya yang lebih terjangkau. Tidak menutup kemungkinan pula, dalam waktu ke depan teknologi ini akan menjadi teknologi yang umum di masyarakat. Perusahaan akan berusaha dan berlomba membuat teknologi ini menjadi produk massal dengan biaya produksi yang rendah. Setiap instansi atau perorangan dapat memiliki dan membuat produknya sendiri dengan mudah dan murah. Dampak dari hal tersebut juga akan membawa dampak perkembangan teknologi rapid prototyping yang terintegrasi dengan benda yang saat ini dimiliki setiap orang yaitu smartphone. Aplikasi-aplikasi smartphone yang menyediakan file-file irisan layer (file stl.) semakin banyak dan orang dapat mengunduh bentuk yang diinginkan dengan gratis.

Dengan perkembangan teknologi informasi saat ini, peluang untuk merancang mesin dengan teknologi rapid prototyping sangat memungkinkan. Penelitian dalam hal desain mesinnya sendiri masih sangat luas. Penambahan hardware seperti bluetooth dan layar sentuh yang terkoneksi internet (cloud) akan semakin memudahkan pengiriman dan penerimaan data yang akan diproses. Peluang pengembangan aplikasi berbasis android dalam mengolah dan menyediaan file berekstensi stl. tentunya akan memicu perkembangan teknologi rapid prototyping lebih pesat lagi. Informasi dan contoh produk dari perusahaan profesional bisa dijadikan acuan dari desain mesin yang akan digunakan pada instansi khususnya instansi pendidikan.

Berikut ini adalah hasil telaah literatur sejumlah peneliti tentang rapid prototyping, diantaranya adalah teknik rapid prototyping merupakan Fused Deposition Modelling (FDM), dengan metode ini model computer aided design 3 dimensi dipersiapkan dan dijadikan input untuk mesin FDM [9]. Kemudian dalam penelitian lain menyebutkan bahwa salah satu mesin FDM yang sering digunakan adalah $3 D$ Printer. Rapid prototyping sangat berguna ketika produk yang dibutuhkan terbatas seperti pembuatan prototipe, iterasi desain, dan optimisasi desain. Mesin FDM ini akan memproses plastik jenis PLA [10]. Parameter model plastik ini dapat dikontrol pada software FDM. Sehingga potensi rapid prototyping dengan teknik FDM dapat dimanfaatkan untuk membuat pola Investment Casting secara efektif [11].

Aplikasi rapid prototyping dalam industri manufaktur, menyebutkan bahwa perkembangan industri manufaktur tidak hanya menuntut untuk menghasilkan produk yang memiliki kualitas lebih baik dan biaya produksi yang relatif rendah dengan produk yang dihasilkan. Pengguna rapid prototyping dapat membantu dalam pengurangan waktu produksi. Proses rapid prototyping menghasilkan produk dalam bentuk 3D tanpa menghasilkan bahan yang terbuang [12].

\section{D Printer}

$3 D$ Printer adalah salah satu jenis mesin FDM. Prinsip kerja dari 3D Printer ini adalah dengan cara memanaskan bahan thermoplastic seperti ABS dan PLA dan di extrusi melalui nosel secara layer by layer. Material ini dinamakan filament, filament dilunakkan dan dilelehkan di dalam proses pencairan hingga pada titik lelehnya dan didorong melalui nosel oleh extruder. Ketika alat pencairan bergerak hasil extrusi thermoplastic tadi tertinggal pada bed sehingga membuat pola benda yang telah diinput pada mesin $3 D$ Printer [13].

Dalam penelitian mengenai aplikasi $3 D$ Printer FDM pada pembuatan pola cor, penggunaan $3 D$ Printer dengan sistem FDM memungkinkan dan layak untuk pembuatan pola cor. Hal ini dikarenakan produk pola yang dihasilkan memiliki bentuk geometri dan ketelitian yang baik. Dengan demikian aplikasi $3 D$ Printer dengan sistem FDM dapat digunakan dalam sektor pengecoran logam dan masih memiliki peluang pengembangan untuk meningkatkan kualitas dari produk yang dihasilkan [14]. 
Pada penelitiannya sebelumnya [4][5], peneliti telah berhasil membuat pola menggunakan kawat pemanas dengan mesin CNC konvensional, namun masih terkendala dengan bentuk yang rumit, geometri dan ketelitian masih rendah. Oleh karena itu, pada penelitian yang diusulkan ini akan dikembangkan pembuatan pola coran menggunakan $3 D$ Printer dengan material resin plastik polyvinyl butyral dan polylactid acid.

\section{Proses Investment Casting}

Investment casting atau dikenal juga lost wax casting adalah salah satu metode pengecoran logam yang sudah digunakan sejak beberapa abad yang lalu. Metode ini dikenal dengan kemampuannya untuk memproduksi suatu komponen dengan permukaan yang baik, akurasi dimensi yang tinggi, dan bentuk yang kompleks. Investment casting ini sangat berguna untuk membuat bentuk-bentuk yang sukar untuk dimesin. Investment casting telah digunakan untuk membuat senjata, perhiasan, dan pengecoran seni pada zaman dahulu. Saat ini aplikasi investment casting sudah sangat berkembang salah satunya pembuatan blade turbine dan komponen mesin lainnya [15].

Prinsip dari investment casting ini adalah membentuk lilin sebagai inti cetakan dengan injection molding. Hasil lilin yang telah dibentuk dilapisi cairan keramik dan didinginkan proses ini sudah terbentuk cetakan investment casting. Setelah didinginkan cetakan dipanaskan hingga lilin meleleh dan hanya tersisa cetakan keramik. Cetakan dipanaskan dengan temperatur yang telah ditentukan lalu logam cair dituangkan ke dalam cetakan. Ketika logam cair sudah dingin cetakan akan dihancurkan dan didapatlah produk akhir dari investment casting. Perkembangan teknologi saat ini investment casting tidak menggunakan lilin sebagai inti cetakannya tetapi menggunakan inti yang dibentuk dengan metode rapid prototyping sehingga pembuatan inti cetakan dapat dilakukan dengan langsung tanpa harus menggunakan metode injection molding [16]. Dalam penelitian tentang rancang bangun sudu turbin kaplan dengan metode rapid prototyping dan investment casting, hasil penelitian ini menunjukan pola terbaik untuk PVB pada temperatur $200^{\circ} \mathrm{C}$ dan untuk PLA pada temperatur $190^{\circ} \mathrm{C}$. Penggunaan pola cetakan PVB dan PLA tidak menunjukkan perbedaan yang signifikan terhadap hasil pengecoran dengan metode investment casting [17]. Adapun proses dari investment casting ditunjukkan pada Gambar 1.
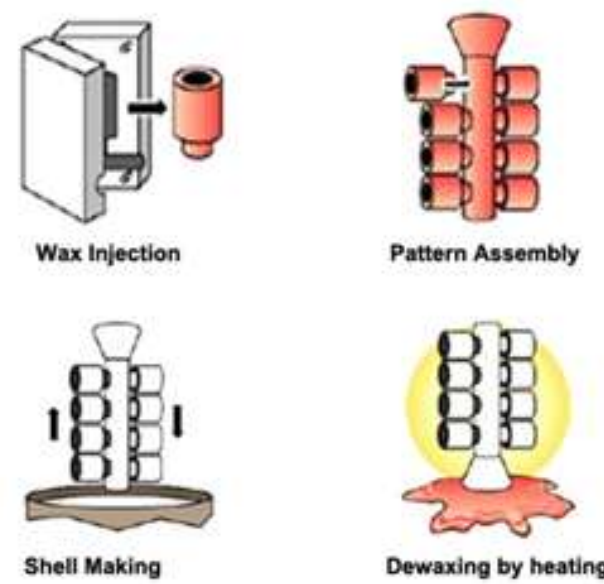

Gambar 1. Proses Investment Casting menggunakan lilin [18]

Kemudian dalam penelitian tentang process development for investment casting of thin-walled components. Hasil penelitian ini menyatakan bahwa pengaruh ketebalan lapisan keramik sangat mempengaruhi cacat penyusutan (shrinkage). Ketebalan lapisan keramik juga mempengaruhi kapasitas penyerapan panas, terutama untuk bentuk yang kompleks dan tipis [19]. Oleh karena itu, pada penelitian ini tidak hanya untuk pengembangan pembuatan pola coran menggunakan $3 D$ Printer namun juga sistem pengecoran dengan metode investment casting khususnya pembuatan prototipe Aluminium cylinder head engine yang berbentuk sirip dan tipis.

\section{Metode Penelitian}

\section{Studi literatur}

Studi literatur dilakukan untuk mencari referensi dan mempelajari lebih lanjut tentang printer 3 dimensi, Rapid Prototyping dan Investment Casting.

\section{Bahan}

Dalam penelitian ini material yang 
digunakan adalah sebagai berikut :

1. Aluminium scrap

2. Filament Polylactic Acid (PLA)

3. Filament Polyvinyl Butyral (PVB)

4. Pasir Silika

5. Semen Gypsum

6. Tanah Kaolin

Alat

Adapun peralatan yang digunakan adalah sebagai berikut :

1. Unit komputer/laptop

2. Printer 3 dimensi

3. Thermocouple tipe K.

4. Tungku Peleburan Logam

5. Tungku Pre-heating Cetakan

6. Aplikasi Autodesk Inventor Professional 2020

\section{Waktu dan tempat penelitian}

Penelitian akan dilaksanakan di Laboratorium Jurusan Teknik Mesin Politeknik Negeri Pontianak dengan target waktu pelaksanaan sekitar enam bulan.

\section{Tahapan penelitian}

a. Tahap pembuatan pola

1) Penggambaran pola menggunakan Autodesk Inventor Professional 2020, dalam penelitian ini dibuat 3 buah pola, yaitu pola pendekatan yang berbentuk sirip-sirip sesuai dengan cylinder head, pola cylinder head, dengan bentuk gating system persegi dan satu pola cylinder head dengan bentuk gating system berbentuk silindris, seperti yang terlihat pada Gambar 2, 3, dan 4.

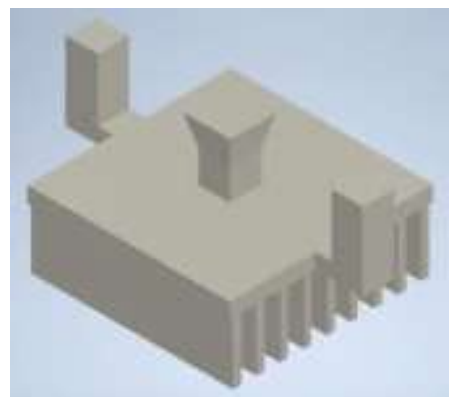

Gambar 2. Model pendekatan dengan gating system

[5]

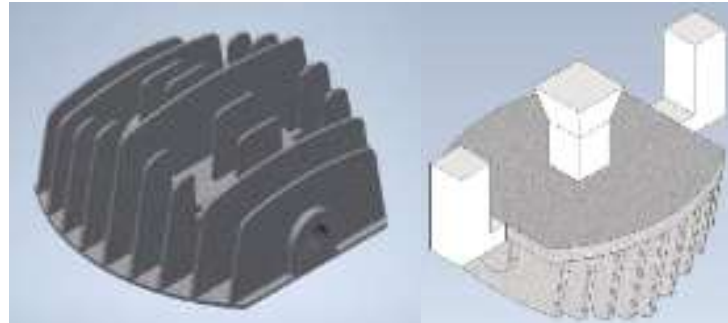

Gambar 3. Produk cylinder head dengan gating system [5]

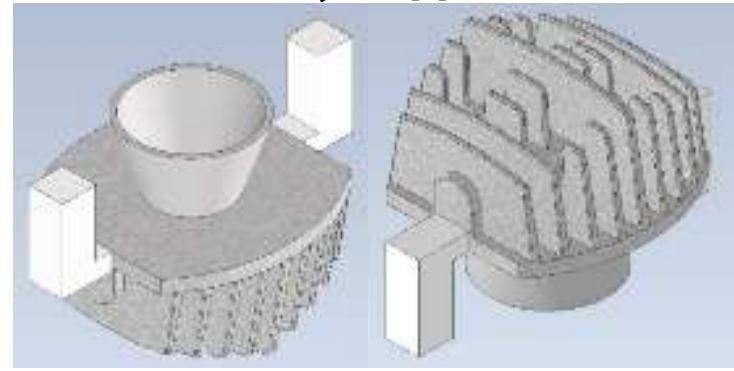

Gambar 4. Produk cylinder head dengan gating system berbentuk silidris

2) Tahap berikutnya adalah pembuatan pola cetakan menggunakan mesin $3 D$ Printer dengan material resin plastik polyvinyl butyral dan polylactid acid. Pada tahapan ini pola pendekatan dan cylinder head engine dicetak dengan infill yang tetap sebesar $10 \%$, layer height sebesar $0.2 \mathrm{~mm}$, dan suhu pencetakan sebesar $200^{\circ} \mathrm{C}$ [12] menggunakan 3D Printing TRONXY. Gambar 5 adalah proses pencetakan pola dengan 3D Printing.

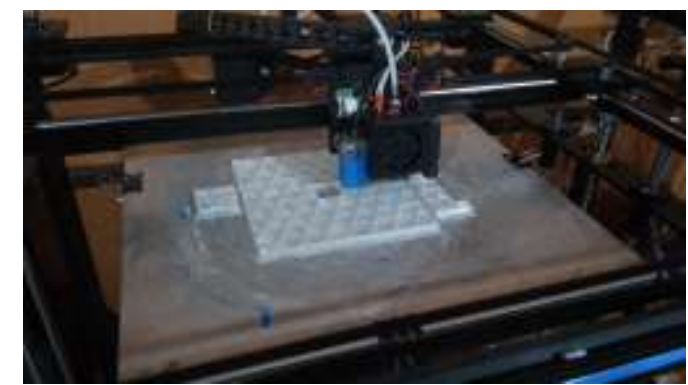

Gambar 5. Proses pencetakan pola menggunakan $3 D$ Printing

b. Tahapan Pembuatan Cetakan Investment Casting

1) Pola cetakan dan gating system disatukan dan dilapisi dengan campuran semen gypsum, pasir silika dan tanah kaolin dengan komposisi 65 $\%$ semen gypsum, $32 \%$ kaolin dan $3 \%$ pasir silika terhadap volume total cetakan. Komposisi ketiga material 
tersebut kemudian diaduk rata dengan air sampai kondisi adukan merata, kemudian dituang ke dalam wadah yang sudah terdapat pola, seperti yang terlihat pada Gambar 6 berikut ini. Pertimbangan pemilihan campuran kaolin, karena kaolin salah satu material refractory. Campuran tersebut kemudian dikeringkan di udara terbuka sampai cetakan membeku, seperti yang terlihat pada Gambar 7.

2) Setelah cetakan membeku proses selanjutnya adalah pembakaran cetakan agar pola yg tertanam dalam cetakan habis terbakar, sehingga membentuk rongga-rongga cetakan, sperti yang terlihat pada Gambar 8 .

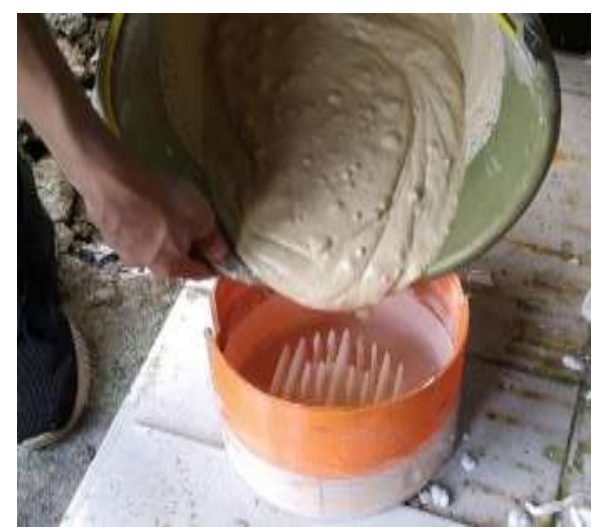

Gambar 6. Proses pembuatan cetakan

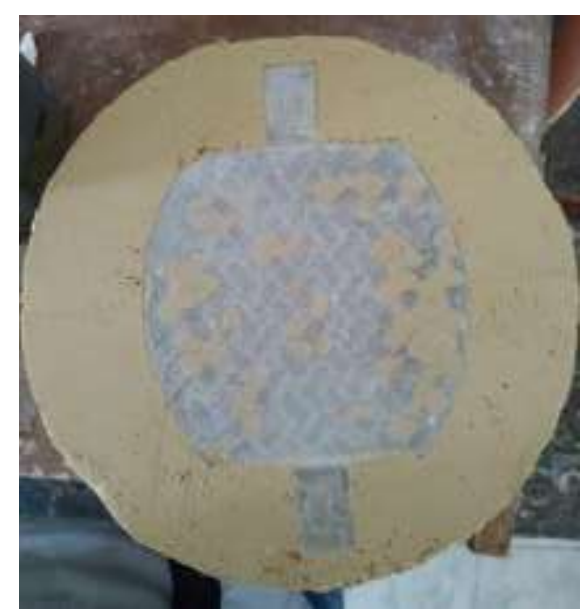

Gambar 7. Cetakan yang sudah ditanam dengan pola

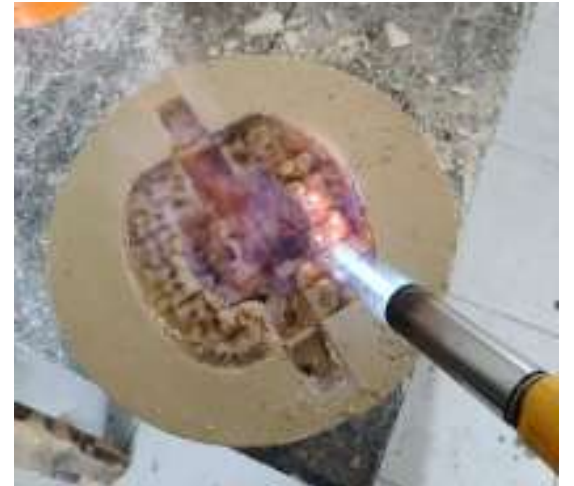

Gambar 8. Proses pembakaran pola di dalam cetakan

c. Tahapan pengecoran

1) Melakukan proses peleburan Aluminium scrap pada temperatur $800^{\circ} \mathrm{C}$, seperti yang terlihat pada Gambar 9.

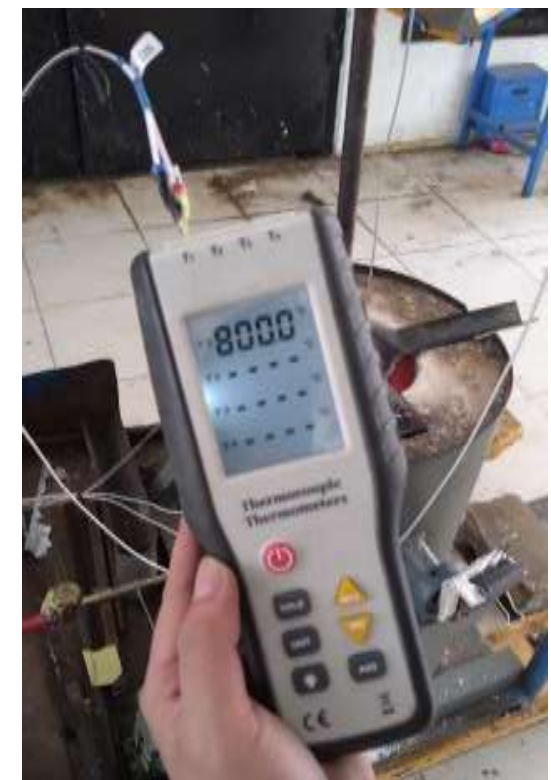

Gambar 9. Proses peleburan dan pengukuran temperatur logam cair

2) Melakukan pre-heating pada cetakan dengan temperatur $300^{\circ} \mathrm{C}$ [17]. Proses pre-heating menggunakan liquefied petroleum gas (LPG), yaitu dengan menempatkan burner di bawah tungku pre-heating sampai temperatur cetakan mencapai $300^{\circ} \mathrm{C}$, seperti yang terlihat pada Gambar 10. 


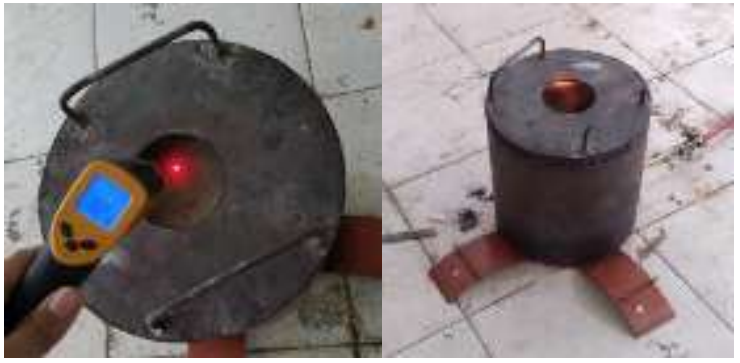

Gambar 10. Proses pre-heating pada cetakan

3) Selama pre-heating pengukuran temperatur dilakukan pada bagian saluran udara tungku pre-heating menggunakan thermocouple tipe $\mathrm{K}$. Proses pre-heating. Adapun hasil hasil pre-heating cetakan dapat dilihat pada Gambar 11.

4) Setelah temperatur cetakan dan logam cair mencapai temperatur yang telah ditentukan, berikutnya adalah proses penuangan logam cair ke dalam cetakan, seperti yang terlihat pada Gambar 12

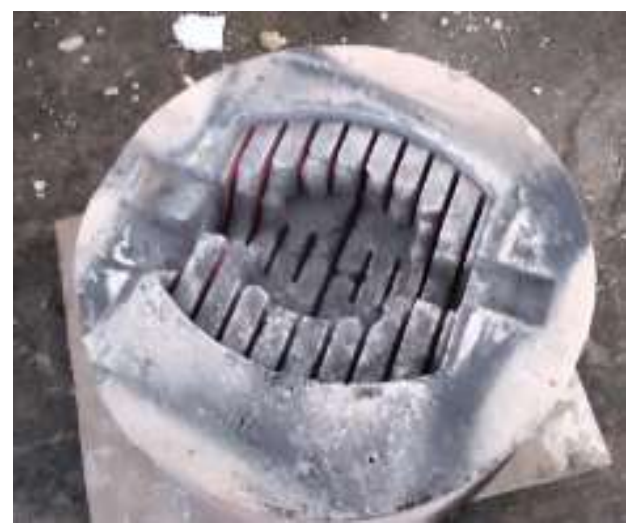

Gambar 11. Hasil pre-heating cetakan

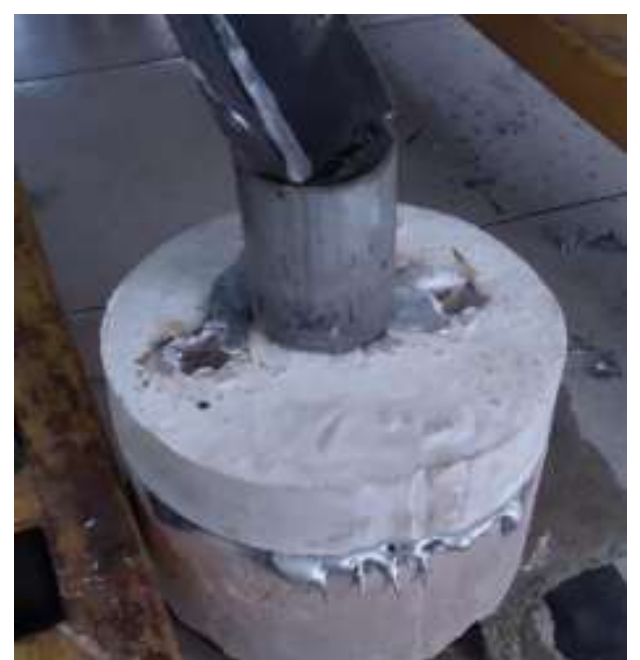

Gambar 12. Proses penuangan logam cair ke dalam cetakan

\section{Hasil dan Pembahasan}

\section{Hasil}

Model pendekatan berbentuk siri-sirip dan head cylinder engine dengan material pola PVB, seperti yang terlihat pada Gambar 13 dan 14. Head cylinder engine dengan material pola PLA ketebalan sirip sama dengan pola pendekatan dan head cylinder engine tanpa ada perubahan ketebalan, seperti yang terlihat pada Gambar 15 dan 16.

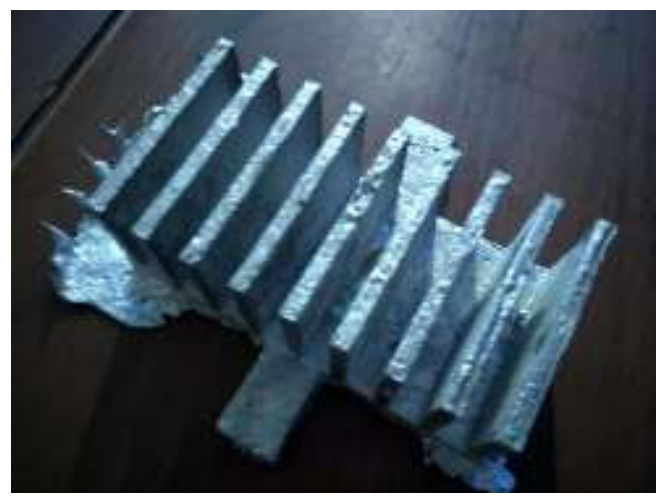

Gambar 13. Model pendekatan berbentuk siri-sirip

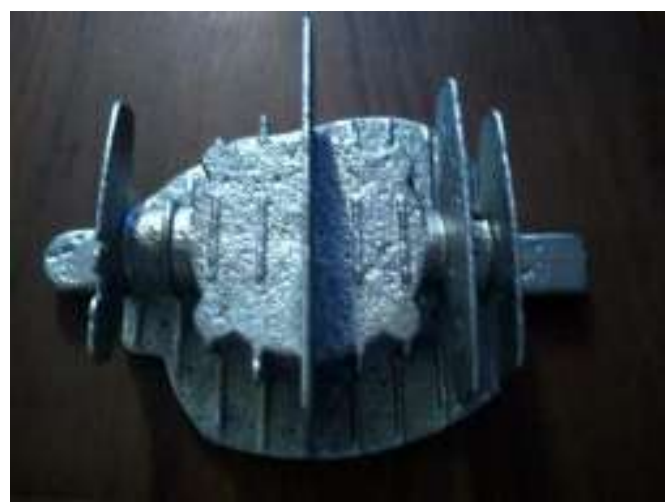

Gambar 14. Head cylinder engine

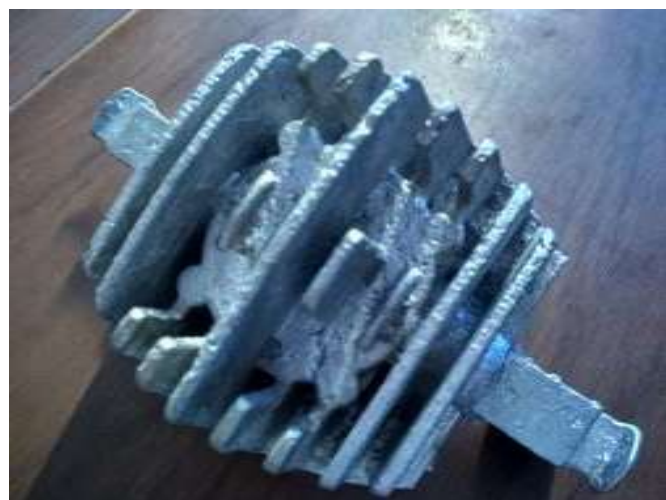

Gambar 15. Head cylinder engine dengan ketebalan sirip sama dengan model pendekatan

Head cylinder engine dengan material pola PVB ketebalan sirip lebih tipis dengan pola pendekatan dan head cylinder engine tanpa ada perubahan ketebalan, kemudian 
bentuk saluran masuk berbentuk silindris, seperti yang terlihat pada Gambar17 dan 18 .

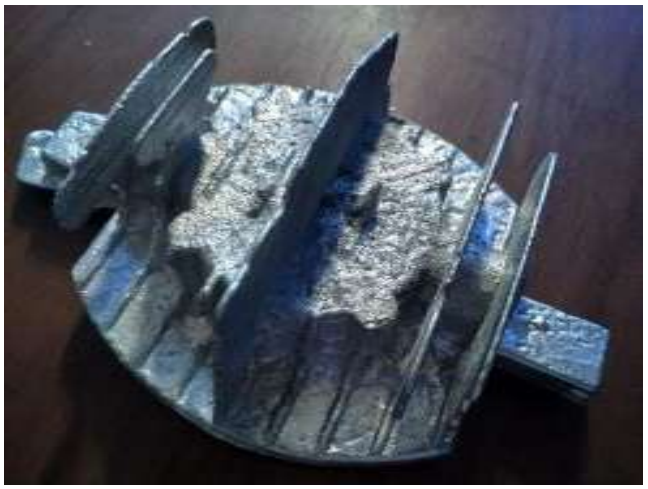

Gambar 16. Head cylinder engine tanpa ada perubahan ketebalan sirip

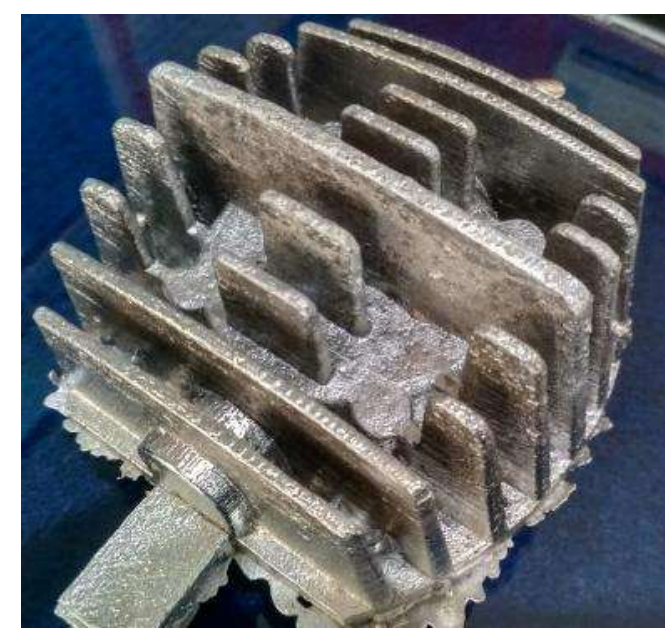

Gambar 17. Head cylinder engine dengan ketebalan sirip lebih tipis dari model pendekatan

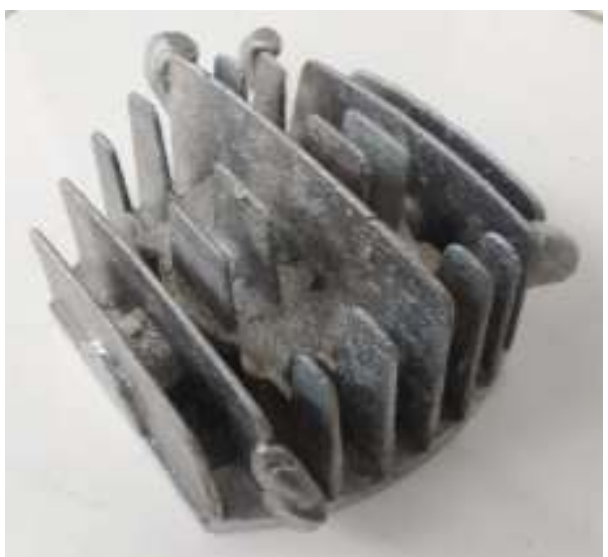

Gambar 18. Head cylinder engine dengan ketebalan sirip tanpa ada perubahan ketebalan sirip

\section{Pembahasan}

Untuk model pendekatan berbentuk sirip Gambar 13 degan material pola PVB, terlihat hasil coran sudah menunjukkan semua bagian sirip dapat terbentuk sempurna, walaupun terdapat sisi dimana dinding cetakan ada yang tergerus yang diduga akibat adanya gesekan antara logam cair dengan dinding cetakan, sehingga terdapat cacat permukaan.

Sedangkan untuk cylinder head engine Gambar 14 dengan material pola PVB, terlihat hasil coran terutama untuk bagian sirip tidak terbentuk sempurna, hal ini diduga masih banyak udara yang terjebak, sehingga logam cair tidak dapat mengisi rongga sirip yang tipis, walaupun sebenarnya terdapat sirip yang hampir terbentuk sempurna.

Kemudian untuk cylinder head engine Gambar 15 dengan material pola PLA, sirip dibuat lebih tebal, terlihat hampir semua sirip terbentuk sempurna, kecuali pada siripsirip bagian tengah (Gambar 19), hal ini juga diduga karena terdapat udara yang terjebak, sehingga sehingga logam cair tidak dapat mengisi rongga sirip tersebut.

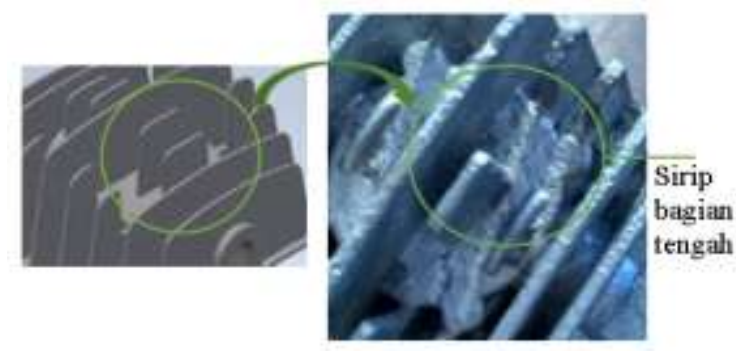

Gambar 19. Perbandingan bagian sirip cylinder head engine bagian tengah

Demikian juga cylinder head engine Gambar 16 material pola PLA dengan sirip yang lebih tipis terlihat hampir semua sirip tidak terbentuk sempurna, hal ini juga diduga karena terdapat udara yang terjebak, sehingga sehingga logam cair tidak dapat mengisi rongga sirip tersebut.

Khusus untuk cylinder head engine Gambar 17 dengan material pola PVB, ukuran sirip dibuat lebih tipis dari pola pendekatan, bentuk saluran masuk berbentuk silindris yang dibuat lebih besar, terlihat bentuk sirip sudah terbentuk sempurna. Hal ini diduga dengan bentuk saluran masuk berbentuk silindris logam cair yang masuk rongga-rongga cetakan lebih merata sehingga tekanan logam cair waktu mengisi rongga cetakan lebih tinggi. Hal ini, diperkuat pada head cylinder engine 
tanpa ada perubahan ketebalan sirip atau ukuran sirip yang sebenarnya terlihat bentuk sirip sudah terbentuk sempurna (Gambar 18). Hal ini diduga logam cair yang masuk ke rongga-rongga cetakan lebih merata sehingga tekanan logam cair waktu mengisi rongga cetakan lebih tinggi, seperti yang terlihat pada Gambar 20. Namun masih terdapat cacat pada beberapa bagian permukaan sirip, hal ini diduga akibat rongga cetakan yang tergerus oleh logam cair, sehingga terdapat cacat berbentuk gumpalan logam cair, seperti yang terlihat pada Gambar 20.

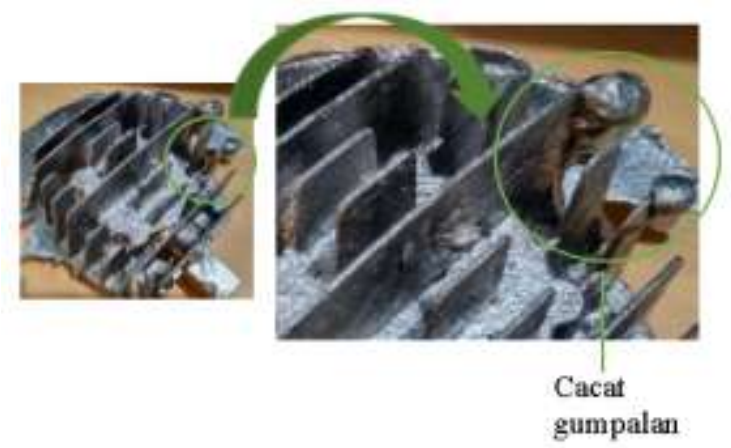

Gambar 20. Cacat yang terjadi pada sirip cylinder head engine dengan saluran masuk berbentuk silindris

Hal lain penyebab ketidaksempurnaan hasil coran adalah faktor penuangan logam cair ke dalam sistem saluran yang belum optimal, sehingga terdapat logam cair yang tidak masuk secara keseluruhan. Selain beberapa hal tersebut di atas, penempatan posisi sistem saluran udara juga menjadi penyebab tidak sempurnya hasil coran. Sementara itu, pengaruh material pola sampai tidak menunjukkan pengaruh terhadap hasil coran. Khusus untuk komposisi material cetakan, dengan adanya unsur material tanah kaolin, secara visual tidak terdapat retak pada cetakan setelah dilakukan pre-heating, hal ini diduga karena faktor material tanah kaolin termasuk jenis material refractory.

\section{Kesimpulan}

Pembuatan pola cylinder head engine dengan metode rapid prototyping dapat dengan mudah dibuat menggunakan mesin $3 D$ Printing. Komposisi material cetakan pasir silika, semen gypsum dan tanah kaolin dapat menghasilkan cetakan yang cukup kuat terlihat dari pre-heating tidak terdapat retak. Bentuk saluran masuk berbentuk silindris menghasilkan coran yang lebih baik dibandingkan dengan saluran masuk berbentuk persegi. Masih terdapat kendala untuk pengecoran bagian-bagian yang tipis, karena masih terdapat udara yang tejebak, sehingga hasil coran tidak sempurna. Pengaruh material pola cetakan tidak memberikan pengaruh yang sigifikan terhadap proses pembuatan cetakan investment casting.

Masih diperlukan kajian yang lebih mendalam terkait dengan gating system pengecoran untuk cylinder head engine dan sebaiknya dilakukan simulasi pengecoran menggunakan aplikasi untuk investment casting terlebih dahulu, maupun variasi temperatur peleburan logam.

\section{Ucapan Terimakasih}

Ucapan terima kasih peneliti sampaikan kepada Jurusan Teknik Mesin Polnep atas bantuan dana yang dianggarkan melalui dana PNBP, hingga selesainya penelitian ini.

\section{Referensi}

[1]. Wibowo, I., 2020, "Menperin Optimistis Industri Manufaktur Dorong Pertumbuhan Ekonomi 2020", Diunduh 26 April 2020, dari https://www.medcom.id/ekonomi/m ikro.

[2]. Deny, S., 2019, "Sektor Manufaktur Indonesia Gencar Adopsi Industri 4.0“, Diunduh 09 Desember 2019, dari

https://www.liputan6.com/bisnis/rea d/4130020/sektor-manufakturindonesia-gencar-adopsi-industri40\#.

[3]. UPPM POLNEP, 2016, "Rencana Induk Penelitian Politeknik Negeri Pontianak 2016-2020", Unit Penelitian dan Pengabdian 
Masyarakat Politeknik Negeri Pontianak.

[4]. Masy'ari, dkk., 2015, "Pembuatan Prototipe Aluminum Cylinder Head Engine Menggunakan Pengecoran Lost Foam Dengan Memanfaatkan Potensi Sumber Daya Mineral Di Wilayah Kalimantan Barat", Laporan Akhir Penelitian Hibah Bersaing Kemenristek Dikti.

[5]. Masy'ari, dkk., 2016, "Pembuatan Prototipe Aluminum Cylinder Head Engine Menggunakan Pengecoran Lost Foam Dengan Memanfaatkan Potensi Sumber Daya Mineral Di Wilayah Kalimantan Barat", Prosiding Seminar Nasional Penerapan Ilmu Pengetahuan dan Teknologi, 2017.

[6] Detijuda F.E., 2019, "Penerapan Teknik Digital Prototyping Dalam Perancangan Dan Pembuatan Model Turbin Cross Flow", Skripsi Prodi D4 Teknik Politeknik Negeri Pontianak.

[7] Masy'ari, dkk., 2019, "Penerapan Teknik Digital Prototyping Dalam Perancangan Dan Pembuatan Model Produk Berbasis Generative Design", Laporan Akhir Penelitian Terapan Politeknik Negeri Pontianak.

[8] Rinanto A, dkk., 2018, "Perkembangan Teknologi Rapid Prototyping: Study Literatur", Jurnal Metris 18 (2017), 105-112.

[9] Williams CB, M. F., 2011, “A Functional Classification Framework For The Conceptual Design Of Additive Manufacturing Technologie", Journal of Manufacturing Processes , 1-11.

[10] Parlad, K., dkk., 2015, "Investigations On Dimensional Accuracy Of The Components Prepared by Hybrid Investment Casting", Journal of Manufacturing Processes 1.

[11] Kumar P, A. I., 2012, “Application Of Fusion Deposition Modelling
Forrapid Investment Casting-A Review", Int. Journal of Material Engineering Innovation., 204.

[12] Lubis, M.S.Y., 2017, "Aplikasi Rapid Prototyping Dalam Industri Manufaktur".

[13] Carneiro, O., dkk., 2015, "Materials \& Design. Fused Deposition Modeling with Polypropylene“" 769.

[14] Abdillah, H., dkk., 2019, "Aplikasi 3d Printer Fused Deposite Material (Fdm) Pada Pembuatan Pola Cor", SINTEK JURNAL, Vol. 13 No. 2.

[15] Pattnaik, dkk., 2012, "Developments In Investment Casting Process-A Review", Journal of Materials Processing Technology, 1.

[16] Rosochwski, dkk., 2000," Rapid Tooling: The State Of The Art", Journal of Materials Processing Technology, 191.

[17] Rasyid, I, M., 2020, "Rancang Bangun Sudu Turbin Kaplan Dengan Metode Rapid Prototyping Dan Investment Casting" Skripsi Prodi D3 Teknik Mesin Politeknik Negeri Pontianak.

[18] Pattnaik, dkk., 2012, "Developments In Investment Casting Process-A Review", Journal of Materials Processing Technology, 1.

[19] Raza, M., 2015, "Process Development For Investment Casting Of Thin-Walled Components: Manufacturing Of Light Weight Components", Mälardalen University Press Licentiate Theses, 199. 